\title{
Training Model of Badminton Footwork for Beginner
}

\author{
Ari Subarkah \\ Pendidikan Kepelatihan Olahraga \\ Fakultas Ilmu Keolahragaan \\ Universitas Negeri Jakarta \\ Jakarta, Indonesia \\ Arytarakan2008@gmail.com
}

\author{
Ika Novitaria \\ Pendidikan Kepelatihan Olahraga \\ Fakultas Ilmu Keolahragaan \\ Universitas Negeri Jakarta \\ Jakarta, Indonesia
}

\begin{abstract}
Changing points in the sport of badminton also entail the pattern of the game. Badminton is a very fast game, and it requires a footwork that is effective and proper. Therefore, this study aims to develop a model of badminton footwork practice based on shadow exercises. The research approach used is the research and development of Borg and Gall. Subjects in this study are 10 beginner athletes, having tested the validity by experts, the attractiveness and feasibility
\end{abstract}

\section{INTRODUCTION}

Badminton is a sport that became the pride of Indonesia. This can be seen from the achievements gained in both regional and international levels although the achievements are currently experiencing ups and downs in the championship, especially in individual events. However, coaching starting from an early age continues to be developed. This is evident from the many regional and national championships which are held continuously. So, consistency is needed in coaching through continuous training.

In sports, achievement can be achieved if athletes master all components of training, namely physical, technical, tactical and mental. However, before the athlete is given physical, tactic or mental training, it is better for the athlete to be given good basic techniques as a basis for the sport. The basic techniques in badminton are: Racket holding, punch, standing attitude, and footwork techniques. One of the most important techniques to be taught during the first time, besides racket holding techniques is the footwork technique.

Footwork techniques are considered important, especially for beginners, because in the game the badminton foot serves as a support for the body to place the body in a position that allows for effective punch movements. A good, agile, fast footwork movement can help the athlete to restore the opponent's shuttlecock with good techniques and can even give the player the opportunity to place the shuttlecock in a place that is difficult to reach because it can reach the shuttlecock given by the opponent. Therefore, good footwork is absolutely needed by a badminton player.

Footwork is the movement of footsteps that regulate the body to place the movement and hit the shuttlecock according to its position. By having good footwork, players are able to reach the point of receiving the ball faster so that the player has the opportunity to manage of the research subjects and the obtained 20 models of badminton footwork exercise in accordance with the purpose of research. So it is expected when the 20 models made are applied in the exercise, they can improve agility in playing badminton.

Keyword-- Training model, Footwork, Badminton

the return of the shuttlecock, hence the opportunity to get points. Mastery of good footwork must be fostered and trained specifically and systematically to get good and right footwork.

According to Syahri Alhusin [1], footwork is used to get closer to the position of the fall of the shuttlecock, so that the player can punch easily. Herman Subarjah [2] continues the footwork as footsteps that regulate the body for hitting the shuttlecock in accordance with its position. Sapta Kunta Purnama [3] also said that footsteps in the badminton game acts as a support for the body to move in all directions quickly, so that it can position the body in such a way as to be able to perform effective punch movements

The above definition shows how important it is to train footwork well. This is also supported by several studies conducted by Yi-Chuang Sheh, etc [4] which is entitled Hop Timing of Split Step and Kinetics Analysis of Lower Extremities in Badminton Start Footwork. The results of the study indicated that the leg that was opposite the movement direction showed significantly greater tower extremity horizontal push-off force than the other leg did. The hop timing of split step is simultaneous with the opponent striking the shuttlecock. The leg opposite the movement direction was the main push leg. This shows that the basic principle of footwork for players who use the right grip is that the right foot is always at the end, or that each step always ends with the right foot.

In addition, there was also research conducted by Heng-Wen Lin, etc, [5] entitled Biomechanical Analysis Of Badminton Different Forward Steps. The results of the study indicate that the movement time for 3-step movement was significantly faster than 2-step. So the 3-step forward badminton footwork seemed to be a better technique to perform net play defense shots in the period of supporting phase of two style forward steps. 
There is also research conducted by Chao Chen [6] entitled Footwork Teaching of College Badminton Elective Course. The results of the study indicate that Badminton Footwork is an important part of the badminton technology, learning and mastering the quick and accurate method is to lay the important link of badminton. In the process of actual learning badminton technology, people often focus on technique study but do not care too much footwork training, it cannot be guaranteed to study results

Therefore, to be able to master good footwork, athletes must be given specific and systematic footwork training so that in doing footwork in playing badminton can be done well. Based on the above problems, the researchers are interested in conducting research on exercise models used for footwork training in badminton. So, it can provide alternative training for trainers in training footwork for their athletes.

\section{METHODOLOGY RESEARCH}

\section{A. Method}

This study aims to develop a footwork training model for badminton. The research method used in this study is research and development methods. The stages of the method used in this research are Sugiyono's research and development. The stages used in this study are:

- Needs Analysis

Preliminary research was carried out with literature studies, field data collection studies, process observations, identification of problems encountered in training for badminton footwork and description and field findings.

- Development Planning Model (Product Design) Make the initial product in the form of a series of model development which can later be used as guidelines or instructions to maximize the results of badminton footwork. The product designed is 20 footwork training models by forming a flat build.

- Design Validation

Validate the design of the model that has been made by the researcher so that it can be tested in the field, whether the model is suitable or unappropriate. This design validation was carried out to improve and refine the training model that was made by the researcher.

- Trial Products in Small Groups

After the exercise model is validated by experts, the next step is to test the footwork training model to the research subjects. Input results from small group trials were used as material to improve the footwork training model in badminton sports.

- Product Revision

Product revisions occur after getting input from experts and product testing in small groups. This is done to reduce or correct models that are not appropriate to train footwork, which must be adjusted to the purpose of this study.

\section{B. Subject}

This study has the characteristics of the subjects, namely: badminton school athletes in FIK UNJ. In this research subject, product trials were carried out in the form of a footwork exercise model with the arrangement of steps - steps that are alternating, successive and jumping steps. Footwork training is done by shadowing. This trial was conducted with the aim of evaluating the footwork training model which are suitable and easy to do for athletes to improve their footwork.

\section{A. Result}

\section{RESULT AND DISCUSSION}

Based on the stages of research and development used, the results of the research can be described as follows:

- Need Analysis

Based on the results of the needs analysis conducted, it can be seen that it is necessary to develop footwork skills training models. The results also suggests that the footwork training model, so far, has not paid attention to the characteristics of trained athletes. In addition, there is lack of enthusiasm of athletes who practice, when given footwork training as well as the level of boredom of athletes in the traditional footwork training model. So, based on the results of the needs analysis, a more varied footwork training model is needed by adjusting to the characteristics of the athlete in order to make the exercise more enjoyable and increase the enthusiasm of the athlete in footwork training.

- Development Planning Model (Product Design).

At this stage, several models have been developed that are based on flat shapes that are carried out in the form of shadow using alternate, successive and jump steps. The model designed is divided into two major models, namely: General shadow training models and 20 models of shadow training exercises. The general shadow training model consists of: Models lurus, Silang, Ke samping, Maju Silang dan Maju Mundur and Maju Lurus Mundur Silang. The special shadow training model consists of: Models Segitiga Sama Kaki, Segitiga Siku - siku, Segitiga Tumpul, Segitiga Lancip, Segitia Sembarang, Persegi, Persegi Panjang, Belah Ketupat, Segilima, Trapesium, Trapesium Sama Kaki, Model Jajaran Genjang and Kubus dan Model Pentigon.

- Expert Validation

At this stage, expert validation of the models that have been designed and developed from the footwork training model above is carried out. The results stated that as many as 8 models got a score of 100 , as many as 1 model got a value of 92 , as many as 
2 models got a score of 83 , as many as 6 models got a value of 75, as many as 1 model got a value of 67 , as many as 1 model scored 58 and as many as 1 model got a score of 42 .

- $\quad$ Trial Products in Small Groups

Small group trials are used to obtain data about the attractiveness and ease of badminton footwork training models. The ujicoa data is taken by giving a questionnaire that contains questions about the attractiveness and ease of the model carried out by the subject. The results of data analysis in filling out questionnaires in small group trials for attractiveness obtained a value of $87.12 \%$ and the ease getting the value of $88.50 \%$.

\section{- Product Revision.}

Based on the results of small group trials and the results of expert validity, there are product revisions that can be done, namely: paying attention to the validity of stepping techniques on each type of step, especially successive steps towards the left, adjusting the rhythm or rhythm of the movement of steps quickly or slowly from each research subject that is tailored to the needs and the last is to pay attention not to miss or not repeat the footwork training point so that it does not waste time.

\section{B. Discussion}

Basically, footwork makes it easier for athletes to make various blows both when hitting or returning a punch that comes. This is because of the efficiency of the power used when punching, where the correct footwork will make it easier for the shuttlecock to always be in front of the position. Donie [7] added that good and correct steps will provide the following benefits: 1) It will be able to move quickly to every point or direction of the field in an effort to return the opponent's blow, 2) Get the highest blow angle because it allows us to move quickly before the cock down, 3) More effective and efficient in the use of power, 4) More free in launching various types of blows quickly, strong, accurate and varied, and 5) Able to make a return-return of a punch from a difficult position.

This is supported by the opinion of Gringe [8] who stated that, previous related studies have provided information useful to competition such as the proper split step timing and which leg should be the primary push-off leg to start footwork. In badminton, the split step is crucial footwork skill. Kuntze, Mansfield \& Sellers [9] also aimed the three different techniques of the badminton footwork and found that the step-in lunge might be beneficial for reducing the muscular demands of lunge recovery.

That's why, it's necessary to give an athlete a combination practice method of footwork, which is following the principles from simple to complex, from easy to difficult, step by step hitting footwork practice as the foundation and footwork combining practice as the focus by the targeted practice. A coach should pay attention to study and master the various footwork comprehensively, to strengthen and improve the athlete's ability to run the court by various means and to strengthen the various steps, adjust skills and improve the training. Hence, the students hold present flexible use of footwork and improve the level of badminton technique and tactics constantly.

Badminton footwork is one of the most fundamental and critical skills in badminton game, which enable players to change positions quickly with excellent motor control. Knowing the kinetics of lunge is not only beneficial for badminton performance but also for injury prevention. The purpose was to analyze the kinetic response between different-leveled badminton players while performing right forward lunge.

\section{CONCLUSION}

Badminton is one fast game that requires a short time to respond to every return shuttlecock. One way to respond to the shuttlecock quickly is to have good footwork. Because the delay in footwork in responding to the shuttlecock given by the opponent is often a failure of the player in returning the shuttlecock, so the player can lose points. Therefore, it is necessary to develop a more varied footwork training model, so that athletes do not feel bored when they have to train footwork. The footwork training model applied in this study is an exercise model that takes into account the level of movement that starts from easy movements to difficult movements. In addition, this exercise model is considered attractive by athletes who have tested this model.

\section{REFERENCES}

[1] Syahri Alhusin, Gemar Bermain Bulutangkis, Surakarta : Seti-Aji, 2007.

[2] Herman Subarjah, Pendekatan Keterampilan Taktik dalam Pembelajaran BULUTANGKIS, Bandung, 2001.

[3] Sapta Kunta Purnama, kepelatihan bulutangkis modern, Surakarta : Yuma Pustaka, 2010.

[4] Yi-chang Sueh, Kuang-Min pan, Chien Lu Tsap, Hop Timing of Split Step and Kinetics Analysis of Lower Extrimities in Badminton Start Footwork, 34rd International Conference on Biomechanis in Sports, Tsukuba, Japan, July, 18 - 22, 2016, pp. $40-43$.

[5] Heng-Wen Lin, Kuei-Shu Huang, Kuang-Min Pan, etc, Biomechanical Analysis Of Badminton Different Forward Steps, $33^{\text {rd }}$ International Conference on Biomechanics in Sports, Poitiers, Fance, June 29 - July 3, 2015, pp. 1066 - 1069.

[6] Chao CHEN, Footwork Teaching of College Badminton Elective Course, 3rd International Conference on Science and Social Research (ICSSR 2014, atlantis press, pp. $281-283$.

[7] Donie, Pembinaan Bulutangkis Prestasi, Padang: Wineka Media,2009.

[8] Grice, T. (2008). Badminton Sfeps to Success (2fh ed). Champaign, I L: Human Kinetics, 2008.

[9] Kuntze, G., Mansfield, N. \& Sellers, W., A biomechanical analysis of common lunge tasks in badminton. Journal of Sports Sciences, 28(2), 2010, pp. 183-191. 